\title{
Intangible assets in information technology projects: identification and evaluation
}

\author{
Margareth Oliveira de Morais* \\ Carlos Francisco Simões Gomes* \\ Priscilla Cristina Cabral Ribeiro*
}

Artículo recibido:

10 de julio de 2020

Artículo aceptado:

11 de septiembre de 2020

Artículo de investigación

\section{Abstract}

This research aims to identify and evaluate intangible assets in a universe of Information Technology (IT) projects among 173 IT professionals in Brazil. The selected research methods were the survey and a literature review, characterized by an exploratory, theoretical reflexive, qualitative and quantitative study. Some recurrent and new intangible assets in IT projects were identified and ratified by the survey's results, expanding the initial list. Among the evaluated methods, none of them was totally adherent to the evaluation of intangible assets in IT projects. However, the relevance

* $\quad$ Fluminense Federal University (UFF), Engineering School, Industrial Engineering Department

mmorais@id.uff.br cfsg1@bol.com.br priscillaribeiro@id.uff.br

INVESTIGACIÓN BIBLIOTECOLÓGICA, vol. 35, núm. 86, enero/marzo, 2021, México, ISSN: 2448-8321 pp. 203-225 
of using methods to evaluate intangible assets related to IT Projects and its benefits were also ratified in the Survey, which signals the need to develop further specific methods and tools for this purpose.

Keywords: Evaluation; Identification; Intangible Assets; Information Technology Projects

Activos intangibles en proyectos de tecnología de la información: identificación y evaluación

Margareth Oliveira de Morais, Carlos Francisco Simões Gomes y Priscilla Cristina Cabral Ribeiro

\section{Resumen}

Esta investigación tiene como objetivo identificar y evaluar activos intangibles en un universo de proyectos de tecnología de la información (TI) con 173 profesionales de TI en Brasil. Los métodos de investigación seleccionados fueron la encuesta y la revisión de la literatura, caracterizados por un estudio exploratorio, teórico reflexivo, cualitativo y cuantitativo. Hay activos intangibles recurrentes y nuevos en proyectos de TI identificados y ratificados por los resultados de la encuesta, ampliando la lista inicial. Entre los métodos evaluados, ninguno de ellos era totalmente adherente a la evaluación de activos intangibles en proyectos de TI. Sin embargo, la relevancia del uso de métodos para evaluar los activos intangibles relacionados con los proyectos de TI y sus beneficios también se ratificó en la encuesta, lo que indica la necesidad de desarrollar métodos y herramientas específicos para este propósito.

Palabras clave: Evaluación; Identificación; Activos Intangibles; Proyectos de Tecnología de la Información 


\section{INTRODUCTION}

Tn recent years, the changes in the growth and stability of national econo1 mies refer to a gradual perspective involving new dimensions such as the significance of intangible assets for the growth of economies (Ökten et al., 2019). The increasing value of intangibles such as knowledge, innovation, copyright, trademarks, brands and patents, virtualization of working, education, and relationships improve the company's competitiveness and profits (Labidi and Gajewski, 2019).

According to Damodaran (2012), the intangible assets are related to human capital, technological vanguard, brand, or the workforce. The term "intangible" can be applied to an asset or to a liability, and this asset would be the company's bad reputation or an insecure work environment (Pastor et al., 2017; Caldas, 2014). Hoss, Rojo, and Grapeggia (2010) joined the assets intellectual capital, human capital and goodwill in a set named "era of knowledge", claiming that "intangible assets" is the term that best represents this category of assets. Hence, intangible assets are present in organizations and their projects, including those of Information Technology (IT), in which technology innovation has been changing the way that the information is used (Alonso Arévalo et al., 2014). Investment in information and communication technologies (ICT) and investment in intangible assets are key sources of growth in advanced economies (Chen, Niebel, and Saam, 2016).

Taking into account that there are risks in IT projects, the knowledge about intangible assets and the methods used to measure their value are fundamental to understand their impact on this kind of project, as well as the potential benefits. Besides, investing in IT - as a necessary intangible asset, according to the large volume of data produced by various agents (Viera, 2017) - is risky, so to reduce this risk, it is necessary to adopt an effective evaluation plan for this kind of investment (Ribeiro, Scavarda, and Batalha, 2008).

In order to contribute to the research about the subject, this paper aims to identify and evaluate intangible assets in a universe of Information Technology (IT) projects with 173 IT professionals in Brazil. The objectives of international bibliography are often very narrow, and they cannot help the corporation in the management of these resources. The bibliographic and field research will answer the secondary questions, as follow:

a) What characterizes an intangible asset?

b) What are the recurring intangible assets in IT projects?

c) What are the main methods for the evaluation of intangible assets?

d) What are the contributions and benefits generated by the application of intangible assets evaluation methods in IT projects and for the organization itself? 
The methodology of this research consists of bibliographic (results are in $\mathrm{Ta}$ bles 1 and 2) and field research. The approaches are qualitative and quantitative, and we chose a survey as a research method. The survey's application was necessary to fill the information gaps caused by the absence of scientific papers that specifically addressed the research subject. Primary research sources were used in a logical-deductive approach, characterizing itself as an exploratory, theoretical-reflexive study. To identify the assets, it was necessary a bibliometric study, where we selected some papers to answer the objectives.

\section{Bibliometric Study}

The bibliometric study carried out in this research followed some steps as Oliveira et al. (2019) and Gomes, Ribeiro and Freire (2018) presented on their papers. First, we searched some articles that are directly addressed to the research subject. After this step, the search and their results led to a selection of articles indirectly related to the research topic, to obtain enough conceptual bases for the research's development. Such theoretical reference aligned to survey outcomes allowed the construction of the knowledge about the research theme.

We searched the articles in three scientific databases: Scopus, Web of Science and SciELO, the time window at the time of the search was from July to January 2020, and 137 articles were reviewed. Besides the articles, it was also used books, thesis, manuals, and best market practices for the research accomplishment.

\section{The constructs}

The next step was to read and summarize the papers to present the constructs in two tables, the intangible assets in IT projects (Table 1) and the intangible assets evaluation methods (Table 2), to answer the main and secondary questions. 


\begin{tabular}{|c|c|c|}
\hline Intangible Asset & Source & Concepts \\
\hline Intellectual Capital & $\begin{array}{l}\text { Pastor et al. (2017); Hoss, } \\
\text { Rojo, and Grapeggia (2010); } \\
\text { OECD (2008) }\end{array}$ & $\begin{array}{l}\text { It includes human resources } \\
\text { and capabilities, organizational } \\
\text { competencies and "relational" } \\
\text { capital, and is named as the "era } \\
\text { of knowledge". }\end{array}$ \\
\hline $\begin{array}{l}\text { Project Manager Experience/Perfor- } \\
\text { mance }\end{array}$ & $\begin{array}{l}\text { Akintoye (2000); Berssaneti, } \\
\text { Carvalho, and Muscat (2015); } \\
\text { Maqbool et al. (2017) }\end{array}$ & $\begin{array}{l}\text { It is the human side of project } \\
\text { management and should be } \\
\text { highlighted on identifying the } \\
\text { skills, technical expertise, } \\
\text { attributes, and qualities of the } \\
\text { manager, and the availability of } \\
\text { the appropriate supervisor. }\end{array}$ \\
\hline Project Manager Leadership & Muller and Turner (2017) & $\begin{array}{l}\text { This professional is the one who } \\
\text { gathers skills at using tools with } \\
\text { appropriate traits and behaviors. }\end{array}$ \\
\hline Project Team Experience & $\begin{array}{l}\text { Akintoye (2000); Chaos } \\
\text { (2015); Kang, Hahn, and } \\
\text { De (2017) }\end{array}$ & $\begin{array}{l}\text { It is a variety of factors leading } \\
\text { roles in successful construction } \\
\text { projects, including the technical } \\
\text { expertise of project teams, } \\
\text { experience, communication } \\
\text { skills, executive sponsorship, } \\
\text { emotional maturity, user } \\
\text { involvement, resources, flexible } \\
\text { processes, modest execu- } \\
\text { tion, adequacy, experience, } \\
\text { performance, projects sharing } \\
\text { customer knowledge. }\end{array}$ \\
\hline $\begin{array}{l}\text { Project-based Work Organizational } \\
\text { Culture }\end{array}$ & $\begin{array}{l}\text { Allaire and Firsirotu (1984); } \\
\text { Van Marrewijk (2007); Jetu, } \\
\text { Riedl, and Roithmayr (2011); } \\
\text { Agustiawan, Coffey, and } \\
\text { Lamari (2019) }\end{array}$ & $\begin{array}{l}\text { The influence of cultural pat- } \\
\text { terns in project team behavior, } \\
\text { during the project life cycle, } \\
\text { interaction among the members } \\
\text { of a team to achieve a better } \\
\text { project outcome. }\end{array}$ \\
\hline $\begin{array}{l}\text { Organizational Culture Oriented to } \\
\text { Innovation and } R \& D\end{array}$ & $\begin{array}{l}\text { Hock, Clauss, and Schulz } \\
\text { (2016); Tian et al. (2018) }\end{array}$ & $\begin{array}{l}\text { When the novelty-oriented } \\
\text { cultural values foster capabilities } \\
\text { (strategic sensitivity, collective } \\
\text { commitment, and resource } \\
\text { fluidity) in favour of business } \\
\text { model innovation. This model is } \\
\text { influenced by different dimen- } \\
\text { sions of both organizational and } \\
\text { national culture. }\end{array}$ \\
\hline Technological Innovation & $\begin{array}{l}\text { Höflinger, Nagel, and Sandner } \\
\text { (2018); Magelssen (2019) }\end{array}$ & $\begin{array}{l}\text { It is the innovative performance } \\
\text { of companies, evaluated by pa- } \\
\text { tents, and is a source of value } \\
\text { creation for multinational com- } \\
\text { panies. }\end{array}$ \\
\hline
\end{tabular}




\begin{tabular}{|c|c|c|}
\hline Intellectual Property & $\begin{array}{l}\text { Sullivan (2000); Thum-Thy- } \\
\text { sen et al. (2017) }\end{array}$ & $\begin{array}{l}\text { The core of what makes compa- } \\
\text { nies competitive, and thus vital } \\
\text { for productivity and economic } \\
\text { growth, and is one of the sustai- } \\
\text { nable competitive advantages } \\
\text { that will build a company's } \\
\text { reputation and market share. }\end{array}$ \\
\hline Brands & $\begin{array}{l}\text { Ahmad (2017); Bank, Yazar, } \\
\text { and Sivri (2020) }\end{array}$ & $\begin{array}{l}\text { It creates long-term competitive } \\
\text { advantage, which implies su- } \\
\text { perior company value, and with } \\
\text { other brand measures should } \\
\text { be combined to improve the } \\
\text { prediction accuracy of customer } \\
\text { satisfaction. }\end{array}$ \\
\hline Sponsorship & $\begin{array}{l}\text { Berssaneti, Carvalho, and } \\
\text { Muscat (2015); Ökten et al. } \\
\text { (2019) }\end{array}$ & $\begin{array}{l}\text { This asset with project mana- } \\
\text { ger's performance are critical } \\
\text { factors for project success. }\end{array}$ \\
\hline Corporate Governance Best Practices & $\begin{array}{l}\text { Jordão and Colauto (2013); } \\
\text { Choudhary and Hoque } \\
\text { (2004); Nazir and Afza } \\
\text { (2018) }\end{array}$ & $\begin{array}{l}\text { It is a system, which controls } \\
\text { companies, intending to meet } \\
\text { the corporation's objectives, } \\
\text { protecting all the stakeholders' } \\
\text { interest and rights. } \\
\text { It controls the opportunistic } \\
\text { behavior of managers, leading } \\
\text { the accounting earnings more } \\
\text { reliable and more informative } \\
\text { for the stakeholders and hence, } \\
\text { increasing the company value. }\end{array}$ \\
\hline
\end{tabular}

Table 1. Intangible Assets in IT Projects

The intangible assets evaluation is somewhat complex (Pastor et al., 2017). There are several methods, but none is considered a universal standard. Table 2 shows the most known method, according to Andriessen (2004) categorization, and some methods that we found in this research.

\begin{tabular}{|l|l|l|}
\hline \multicolumn{1}{|c|}{ Method } & \multicolumn{1}{|c|}{ Authors } & \multicolumn{1}{c|}{ Aims } \\
\hline $\begin{array}{l}\text { EVA (Eco- } \\
\text { nomic Value }\end{array}$ & $\begin{array}{l}\text { Stewart (1997); Hoss, Rojo, and Grapeggia } \\
\text { (2010); Andriessen (2004); Kayo et al. } \\
\text { (2006); Duffy (2000) }\end{array}$ & $\begin{array}{l}\text { Improving the internal organization, mainly } \\
\text { the decision making. } \\
\end{array}$ \\
& & $\begin{array}{l}\text { Generate financial reports to external } \\
\text { stakeholders. }\end{array}$ \\
& \\
\hline
\end{tabular}




\begin{tabular}{|c|c|c|}
\hline $\begin{array}{l}\text { Cost, market } \\
\text { and income } \\
\text { approaches }\end{array}$ & $\begin{array}{l}\text { Andriessen (2004); Parr and Smith (1994); } \\
\text { Reilly and Schweihs (1998) }\end{array}$ & $\begin{array}{l}\text { Supporting companies or regulatory } \\
\text { institutions to bureaucracy's demands, and } \\
\text { management decisions. }\end{array}$ \\
\hline $\begin{array}{l}\text { Market-to- } \\
\text { book ratio }\end{array}$ & $\begin{array}{l}\text { Stewart (1997); Hoss, Rojo, and Grapeggia } \\
\text { (2010); Andriessen (2004) }\end{array}$ & $\begin{array}{l}\text { Improving the internal organization, and } \\
\text { generating financial reports to external } \\
\text { stakeholders. }\end{array}$ \\
\hline Tobin's Q & $\begin{array}{l}\text { Stewart (1997); Bontis, Crossan, and } \\
\text { Hulland (2002); Wang (2013); Hoss, Rojo, } \\
\text { and Grapeggia (2010); Andriessen (2004) }\end{array}$ & $\begin{array}{l}\text { Measuring the performance of Intellectual } \\
\text { Capital, improving the internal adminis- } \\
\text { tration, and generating financial reports to } \\
\text { external stakeholders. }\end{array}$ \\
\hline $\begin{array}{l}\text { Calculated } \\
\text { intangible } \\
\text { value }\end{array}$ & $\begin{array}{l}\text { Stewart (1997); Luthy (1998); Hoss, Rojo, } \\
\text { and Grapeggia (2010); Andriessen (2004) }\end{array}$ & $\begin{array}{l}\text { Supporting companies or regulatory } \\
\text { institutions to bureaucracy's demands, } \\
\text { management decisions. }\end{array}$ \\
\hline $\begin{array}{l}\text { Skandia } \\
\text { navigator }\end{array}$ & $\begin{array}{l}\text { Edvinsson and Malone (1997); Hoss, Rojo, } \\
\text { and Grapeggia (2010); Andriessen (2004); } \\
\text { Duffy (2000) }\end{array}$ & $\begin{array}{l}\text { Improving the internal organization, and } \\
\text { generating financial reports to external } \\
\text { stakeholders by dynamic and differentiate } \\
\text { data to reduce the informational asymmetry. }\end{array}$ \\
\hline $\begin{array}{l}\text { The Intan- } \\
\text { gible Asset } \\
\text { Monitor }\end{array}$ & $\begin{array}{l}\text { Sveiby (1997); Hoss, Rojo, and Grapeggia } \\
\text { (2010); Andriessen (2004) }\end{array}$ & $\begin{array}{l}\text { Improving the internal organization, and } \\
\text { generating financial reports to external } \\
\text { stakeholders. }\end{array}$ \\
\hline $\begin{array}{l}\text { IC (Intellec- } \\
\text { tual Capital) } \\
\text { index }\end{array}$ & $\begin{array}{l}\text { Roos (1998); Hoss, Rojo, and Grapeggia } \\
\text { (2010); Andriessen (2004); Duffy (2000); } \\
\text { Massingham (2015); Calabrese, Costa, } \\
\text { and Menichini (2013) }\end{array}$ & $\begin{array}{l}\text { Capturing the maximum value of an } \\
\text { individual's knowledge, improving the value } \\
\text { of organization. } \\
\text { Evaluating the impact of Intellectual Capital } \\
\text { in value creation for organizations. }\end{array}$ \\
\hline
\end{tabular}




\begin{tabular}{|c|c|c|}
\hline $\begin{array}{l}\text { Balanced } \\
\text { Scorecard }\end{array}$ & $\begin{array}{l}\text { Kaplan and Norton (1992); Hoss, Rojo, and } \\
\text { Grapeggia (2010); Andriessen (2004); } \\
\text { Boj, Rodriguez-Rodriguez, and Alfaro-Saiz } \\
\text { (2014) }\end{array}$ & $\begin{array}{l}\text { Measuring the organization's performance, } \\
\text { improving its results. } \\
\text { The Analytic Network Process (ANP) is a } \\
\text { tool that assesses how intangible assets im- } \\
\text { pact the achievement of strategic objectives. }\end{array}$ \\
\hline $\begin{array}{l}\text { Business } \\
\text { Model }\end{array}$ & Spender et al. (2013) & $\begin{array}{l}\text { Estimating the future value of intangible } \\
\text { assets. }\end{array}$ \\
\hline $\begin{array}{l}\text { Organization } \\
\text { reputation }\end{array}$ & Caldas (2014) & $\begin{array}{l}\text { Using The "Matrix of Intangible Elements", } \\
\text { the company can evaluate the response } \\
\text { speed and the representativeness (ordering } \\
\text { by weights) of intangible assets. }\end{array}$ \\
\hline Patents & $\begin{array}{l}\text { Clausen and Hirth (2016); Adriano and } \\
\text { Antunes (2017) }\end{array}$ & $\begin{array}{l}\text { Measuring the gains for the value of intangi- } \\
\text { bles, such as patents. }\end{array}$ \\
\hline $\begin{array}{l}\text { The discoun- } \\
\text { ted cash } \\
\text { flow model } \\
\text { and the } \\
\text { real options } \\
\text { model }\end{array}$ & De Carvalho et al. (2019) & $\begin{array}{l}\text { The model assesses where the value of } \\
\text { the asset is obtained by adding the present } \\
\text { values of the projected cash flow, and the } \\
\text { flexibility of the asset. }\end{array}$ \\
\hline
\end{tabular}

Table 2. Intangible Assets Evaluation Methods

Source: adapted from Andriessen (2004)

The criteria used to select the assets are:

a) Information obtained integrally (or adapted) from scientific articles listed in the literature review;

b) Contributions resulting from the preliminary evaluation of the field research (survey);

c) Contributions based on the researchers' professional experience as an IT project manager. 


\section{The Step By Step Survey}

Therefore, this is a type of "unidentified" survey, there is no way to identify the respondent or the organization where he/she works. The Survey intends to answer the four secondary research questions presented in the introduction, as we can see in Table 3.

\begin{tabular}{|l|l|}
\hline \multicolumn{1}{|c|}{ Research questions } & \multicolumn{1}{|c|}{ Actions } \\
\hline What are the main intangible assets? & Table 1 \\
\hline $\begin{array}{l}\text { What are the recurring intangible assets in IT } \\
\text { projects? }\end{array}$ & Table 1 and survey \\
\hline $\begin{array}{l}\text { What are the main methods for the evaluation of } \\
\text { intangible assets? }\end{array}$ & Table 2 and survey \\
\hline $\begin{array}{l}\text { What are the contributions and benefits generated } \\
\text { by the application of Intangible Assets evaluation } \\
\text { methods in IT projects and for the organization itself? }\end{array}$ & Survey \\
\hline
\end{tabular}

Table 3. Actions performed to answer the secondary research questions

A questionnaire was developed and used as a data collection tool, in some steps:

- First step: the initial list of recurring intangible assets in IT projects was created, as can be seen in Table 1. The used data collection tool is a questionnaire developed by the researchers and it has ten questions (open and closed);

- Second step: the research statistical bases were defined, such as target audience, the universe of research, the margin of error and degree of confidence, type and size of the sample;

- Third step: the first version of the questionnaire was analysed by the first group of 10 IT professionals. They work for public and private organizations located in Brazil. They presented and contributed to improving the questionnaire with many suggestions;

- Fourth step: the second group of IT professionals answered the questionnaire's final version, thus characterizing itself as a pilot test of the research instrument;

- Fifth step: we applied the questionnaire to the target audience, mainly by social networks;

- Sixth step: refers to the analysis of results and the registry of main findings and conclusions. 
The questionnaire was supported by Survey Monkey ${ }^{\circledR}$ software. Due to time and budget constraints, the questionnaire was applied through LinkedIn and Facebook social networks, in specific groups, restricted to IT professionals. It was also released via e-mail and WhatsApp. The link disclosure to access the survey was preceded by a presentation text, describing the target audience and survey proposal. As the questionnaire was answered, the results were automatically recorded, consolidated, stored and made available to the researcher on the Survey Monkey® software site (https://en.surveymonkey. $\mathrm{com} /$ ) under controlled access. In the Appendix, there are the questionnaire and the answers.

The target audience for this survey is IT professionals, who are residents in Brazil and have some experience in IT projects. For Sweeney, Thomas, and Anderson (2015), when the population is extremely large and contains elements generated in a continuous process, it can be classified as infinite. According to these authors, it is advisable to use "random" sampling for this type of population. However, due to the time, cost and survey applying method (through social networks), convenience sampling was chosen. The characteristics of the respondents are in Table 4.

\begin{tabular}{|l|c|}
\hline \multicolumn{1}{|c|}{ Questions } & Answers \\
\hline 1. Region & Southeast \\
\hline 2. He/she has academic IT education & $74.49 \%$ \\
\hline 3. He/she acts professionally in IT area & $84.69 \%$ \\
\hline 4. He/she has an experience as technicians / experts / consultants & $75 \%$ \\
\hline 5. He/she has never acted in IT Projects & $11.7 \%$ \\
\hline 6. He/she has more than 10 years of IT projects experience & $36.73 \%$ \\
\hline 7. He/she does not have IT projects experience & $11.73 \%$ \\
\hline
\end{tabular}

Table 4. The respondents' characteristics

As the standard deviation is unknown, the sample size was calculated from a population proportion equal to 0.5 , considering a confidence level of $95 \%$ and a margin of error equal to $7 \%$. According to Sweeney, Thomas, and Anderson (2015), the margin of error used to estimate a population proportion is up to $10 \%$. The maximum value of the population proportion $(p)$ was used to ensure that the sample size is enough for the desired margin of error to be preserved. Equation 1 shows how to calculate the sample size: 


\section{$n=\frac{\left(z_{\alpha / 2}\right)^{2} p(1-p)}{E^{2}}$}

$n=$ Sample size

$p=$ Sample proportion

$z_{\alpha / 2}=Z$ value defines the area of $\alpha / 2$ in the upper tail (normal distribution)

Confidence Level $=95 \%$

$E=$ margin of error

For this research, equation 2 shows how we calculated the sample size:

$$
n=\frac{(1,96)^{2} * 0,5 *(1-0,5)}{(0,07)^{2}}
$$

Based on the previous calculation (2), the target sample size is 196 respondents, with a margin of error of $7 \%$. Considering the maximum tolerated margin of error $(10 \%)$, the minimum sample size would be 96 respondents.

The survey data collection was closed on December 2018, and 197 respondents answered the questionnaire. Through a comparative analysis of individual responses to questions 1, 3, 4 and 5, it was noticed that 24 respondents did not fully correspond to the survey target audience profile (IT professionals living in Brazil and having some experience in IT projects). Their respective individual questionnaires were identified, segregated and their answers were disregarded. After the data analysis, the sample size was adjusted to 173 respondents, which implies a margin of error of around $7.5 \%$.

\section{Results AnAlysis}

Concerning to culture of projects, some respondents $(28.3 \%)$ said that they work in organizations where it exists, but they do not have a project management's office. A percentage of $44.5 \%$ of respondents answered that they work in places where both culture and project management's offices exist, with different control levels (low, medium and high). Thus, most of them $(72.8 \%)$ work in an organization where there already is a developed project culture, which gives them maturity to participate in this research. 
Most of the respondents work in complex organizations, with large companies standing out $(46.8 \%$ of the total sample). In total, they are distributed between commerce $(58.4 \%)$ and industry $(30 \%)$, where there is a greater need to control the projects. Table 5 summarizes these results.

\begin{tabular}{|c|c|c|c|c|}
\hline Question & Answer & \multicolumn{3}{|c|}{ Percentage } \\
\hline \multirow[t]{5}{*}{$\begin{array}{l}\text { How is the project culture } \\
\text { where you work? }\end{array}$} & $\begin{array}{l}\text { There is not a project } \\
\text { culture }\end{array}$ & \multicolumn{3}{|c|}{$27.2 \%$} \\
\hline & $\begin{array}{l}\text { There is a project culture, } \\
\text { but there are not project } \\
\text { offices }\end{array}$ & \multicolumn{3}{|c|}{$28.3 \%$} \\
\hline & \multirow{3}{*}{$\begin{array}{l}\text { There are culture and } \\
\text { project offices }\end{array}$} & Low level & $17.9 \%$ & \multirow{3}{*}{$44.5 \%$} \\
\hline & & Medium level & $16.8 \%$ & \\
\hline & & High level & $9.8 \%$ & \\
\hline \multirow{5}{*}{$\begin{array}{l}\text { What is the size of the com- } \\
\text { pany where you work? }\end{array}$} & Large & \multicolumn{3}{|c|}{$46.8 \%$} \\
\hline & Medium & \multicolumn{3}{|c|}{$13.3 \%$} \\
\hline & Small & \multicolumn{3}{|c|}{$13.3 \%$} \\
\hline & Micro & \multicolumn{3}{|c|}{$15 \%$} \\
\hline & Others & \multicolumn{3}{|c|}{$11.6 \%$} \\
\hline \multirow[t]{3}{*}{ What is the sector? } & Commerce & \multicolumn{3}{|c|}{$58.4 \%$} \\
\hline & Industry & \multicolumn{3}{|c|}{$30 \%$} \\
\hline & Others & \multicolumn{3}{|c|}{$11.6 \%$} \\
\hline
\end{tabular}

Table 5. The sizes and sectors of the organizations

During the application of the questionnaire, some intangible assets were suggested by the respondents and they are in Table 6, such as IT Reputation, Agile Culture, Culture of IT Project Alignment to Corporate Strategic Planning, Meeting the Stakeholder Expectations, Specialized Knowledge About the Business/Project Delivery Area, Social Asset (sustainability). Some of the assets that are in the literature review are part of our background and were supported by some scientific sources, as we can see in Table 1 . 


\section{Discussion}

After the application of questionnaire, the validation of intangible assets considered as recurrent in IT projects - was done, and the majority of them (12 in 17) were ratified with a level of adherence up to $70 \%$, four assets were ratified between $60 \%$ and $70 \%$, and just one asset showed a level between $50 \%$ and $60 \%$. The ranking was divided into three categories, according to the adherence levels, and to lead to analyze the relevance of these intangible assets in IT projects.

The percentages were obtained from the data consolidation from eight question's answers, adding for each asset the total percentage of each answer that connects at a higher or lower level to the IT projects. The scale is:

A - It is an intangible asset and could be present in all/ majority IT projects;

$\mathrm{B}$ - It is an intangible asset that could be present in many IT projects;

C - It is an intangible asset that could be present in some IT projects;

Table 6 presents the ranking of the assets and their levels.

\begin{tabular}{|c|c|c|}
\hline Assets & Ranking & Levels \\
\hline Project Team Experience & 86.12 & \multirow[t]{12}{*}{ A } \\
\hline Intellectual Capital & 84.4 & \\
\hline Project Manager Experience/Performance & 84.4 & \\
\hline Specialized Knowledge About the Business/Project Delivery Area & 83.82 & \\
\hline Project Manager Leadership & 82.08 & \\
\hline Project-based Work Organizational Culture & 78.03 & \\
\hline Agile Culture & 77.45 & \\
\hline Meeting the Stakeholder Expectations & 77.46 & \\
\hline Technological Innovation & 76.87 & \\
\hline IT Reputation & 73.99 & \\
\hline Culture of IT Project Alignment to Corporate Strategic Planning & 73.99 & \\
\hline Corporate Governance Best Practices & 73.99 & \\
\hline Intellectual Property & 65.32 & \multirow[t]{4}{*}{ B } \\
\hline Organizational Culture Oriented to Innovation and R\&D & 65.32 & \\
\hline Sponsorship & 65.31 & \\
\hline Social Asset (sustainability) & 61.27 & \\
\hline Brands & 52.6 & C \\
\hline
\end{tabular}

Table 6. Ranking of the intangible assets - confirmation 
After that, the respondents suggested seven new intangible assets:

- Organizational Process Assets;

- Negotiation skills;

- Culture for projects execution with multicultural teams;

- Culture for projects execution with teams geographically distributed;

- Project lessons learned;

- Creativity;

- Readiness and respect for projects deadlines and costs.

The second part of the research was to check the evaluation methods and if it is possible to identify contributions and benefits generated by the application of Intangible Assets evaluation methods in IT projects and for the organization itself. These benefits can be cumulative. Thus, the respondent can assign one or more options, and they considered that the use of methods for evaluating intangible assets might contribute:

- To a better IT projects evaluation $(67.63 \%)$;

- To a better IT projects risk assessment (59.54\%);

- To a better organization evaluation $(52.6 \%)$.

A percentage of $21.96 \%$ has declared not able to evaluate or comment on the subject. A percentage of $2.89 \%$ considered the application of such methods irrelevant.

\section{Conclusions}

The research questions and objectives were satisfied, the recurrent intangible assets in IT Projects were identified (Table 1) and were ratified in survey, and new ones were identified, expanding the initial list.

The relevance of using methods to evaluate intangible assets in the context of IT Projects and the benefits associated with this evaluation was also ratified in the survey, corroborating the assumptions supported by the researcher.

Among the evaluated methods, none was identified as totally adherent to the evaluation of intangible assets in IT projects, which indicates the need to develop methods and tools for this purpose.

We did not find articles or other studies dealing specifically with the identification and evaluation of intangible assets in IT projects, just indirectly 
related material. This difficulty can be considered as an opportunity for such a study to be relevant to the scientific community and a stimulus for further research on the subject to be developed in the future.

Finally, the lack of studies on the subject and the difficulty in the objective treatment of intangible assets within organizations and projects reinforce the need to reflect on their existence and relevance. The evaluation methods did not support the research, what leads us to understand that it is necessary to develop methods and tools that fully respond to identify, evaluate, measure and manage them to take full advantage of the benefits they can generate.

\section{LIMITATIONS AND FUTURE RESEARCH}

The limitations of the research are related to apply open questions in a survey research method, the answers were not quite simple, hard to analyze in depth. Even though the sample has an appropriate number of respondents, they work in different sectors. If they are in the same sector, have the same size, and are the same agent of the supply chain (i.e, a producer, an industry or a retailer) the answers will allow the researchers to compare in the same scenario with similar conditions.

The future research can develop a new method to assess the intangible assets, searching for variables to build a set of them, in a sector, applying questionnaires in a multiple case study. To analyze the answers, the researchers could use the content analysis.

\section{REFERENCES}

Adriano, E. and M. T. P. Antunes. 2017. "Proposta para mensuração de patentes." Revista de Administração Contemporânea 21 (1): 125-141. https://doi.org/10.1590/1982-7849rac201700123

Agustiawan, Y., V. Coffey, and F. Lamari. 2019. "Improving relationship quality between main contractors and sub-contractors in Indonesian Infrastructure Projects." Paper presented at International Conference on Advances in Civil and Environmental Engineering (ICAnCEE 2018), Bali, Indonesia, October 24th-25th.

Ahmad, A. 2017. "Evaluation of the relationship between brand measures and customer satisfaction by using data mining techniques." Journal of Intelligent \& Fuzzy Systems 33 (4): 2451-2462. https://doi.org/10.3233/JIFS-17573

Akintoye, A. 2000. "Analysis of factors influencing project cost estimating practice." Construction Management E Economics 18 (1): 77-89. https://doi.org/10.1080/014461900370979 
Allaire, Y. and M. E. Firsirotu. 1984. "Theories of organizational culture.” Organization Studies 5 (3): 193-226. https://doi.org/10.1177/017084068400500301

Alonso Arévalo, J., J. A. C. García, R. G. Díaz, and B. G. Giménez. 2014. “Uso y aplicación de herramientas 2.0 en los servicios, producción, organización y difusión de la información en la biblioteca universitaria." Investigación bibliotecológica 28 (64): 51-74.

Andriessen, D. 2004. "IC valuation and measurement: classifying the state of the art." Journal of Intellectual Capital 5 (2): 230-242. https://doi.org/10.1108/14691930410533669

Bank, S., E. E. Yazar, and U. Sivri. 2020. "The portfolios with strong brand value: More returns? Lower risk?” Borsa Istanbul Review 20 (1): 64-79. https://doi.org/10.1016/j.bir.2019.09.001

Berssaneti, F. T., M. M. de Carvalho, and A. R. N. Muscat. 2015. "O impacto de fatores críticos de sucesso e da maturidade em gerenciamento de projetos no desempenho: um levantamento com empresas brasileiras." Production 26 (4): 707-723. https://doi.org/10.1590/0103-6513.065012

Boj, J. J., R. Rodriguez-Rodriguez, and J. J. Alfaro-Saiz. 2014. "An ANP-multi-criteria-based methodology to link intangible assets and organizational Performance in a Balanced Scorecard context." Decision Support Systems 68: 98-110. https://doi.org/10.1016/j.dss.2014.10.002

Bontis, N., M. M. Crossan, and J. Hulland. 2002. "Managing an organizational learning system by aligning stocks and flows." Journal of Management Studies 39 (4): 437-469. https://doi.org/10.1111/1467-6486.t01-1-00299

Calabrese, A., R. Costa, and T. Menichini. 2013. "Using Fuzzy AHP to manage Intellectual Capital assets: An application to the ICT service industry." Expert Systems with Applications 40: 3747-3755. https://doi.org/10.1016/j.eswa.2012.12.081

Caldas, S. L. 2014. Intangiveis: O Lado Oculto da Gestão Empresarial. Rio de Janeiro: Digitaliza.

Chaos. 2015. Chaos Report 2015. Massachusetts: The Standish Group.

Chen, W., T. Niebel, and M. Saam. 2016. "Are intangibles more productive in ICT-intensive industries? Evidence from EU countries.” Telecommunications Policy 40 (5): 471-484.

https://doi.org/10.1016/j.telpol.2015.09.010

Choudhary, M. and M. Z. Hoque. 2004. An Advanced Exposition of Islamic Economics and Finance. New York: Edward Mellen Press.

Clausen, S. and S. Hirth. 2016. "Measuring the value of intangibles." Journal of Corporate Finance 4: 110-127. https://doi.org/10.1016/j.jcorpfin.2016.07.012

Damodaran, A. 2012. Valuation. Rio de Janeiro: LTC - Livros Técnicos e Científicos Editora Ltda.

Davis, K. 2014. "Different stakeholder groups and their perceptions of project success.” International Journal of Project Management 32 (2): 189-201. https://doi.org/10.1016/j.ijproman.2013.02.006 
De Carvalho, G. A., H. F. Amaral, P. O. de S. Batista, and J. E. Ribeiro. 2019. "Valoração de ativos intangíveis com opções reais: estudo de caso em uma transferência de tecnologia da Universidade Federal de Minas Gerais." Navus-Revista de Gestão e Tecnologia 9 (2): 07-23.

https://doi.org/10.22279/navus.2019.v9n2.p07-23.740

Duffy, J. 2000. "Knowledge management: What every information professional should know". Information Management 34 (3): 10.

Edvinsson, L. and M. S. Malone. 1997. Intellectual Capital: Realizing your Company's True Value by Finding its Hidden Brainpower. New York: Harper Business.

Emmanouil, G. and G. Dimitrios. 2017. "Measure the unmeasurable? intangible assets as the major strategic keys of enterprises, their contribution, difficulties and proposals for reliable financial statements." David Publishing Company 16 (12): 594-608. https://doi.org/10.17265/1537-1506/2017.12.002

Gomes, C. F. S., P. C. C. Ribeiro, and K. A. M. Freire. 2018. "Bibliometric research in Warehouse Management System from 2006 to 2016." Paper presented at World Multi-Conference on Systemics, Cybernetics and Informatics, Orlando, USA, July 8th-11th.

Hock, M., T. Clauss, and E. Schulz. 2016. "The impact of organizational culture on a firm's capability to innovate the business model." RED Management 46 (3): 433-450. https://doi.org/10.1111/radm.12153

Höflinger, P; J., C. Nagel, and P. Sandner. 2018. "Reputation for technological innovation: Does it actually cohere with innovative activity?” Journal of Innovation $\mathcal{E}$ Knowledge 3 (1): 26-39. https://doi.org/10.1016/j.jik.2017.08.002

Hoss, O., C. A. Rojo, and M. Grapeggia. 2010. Gestão de Ativos Intangiveis. São Paulo: Atlas.

Jetu, F. T., R. Riedl, and F. Roithmayr. 2011. "Cultural patterns influencing project team behavior in Sub-Saharan Africa: A case study in Ethiopia." Project Management Journal 42 (5): 57-77. https://doi.org/10.1002/pmj.20260.

Jordão, R. and R. Colauto. 2013. "Evidenciação voluntária de ativos intangíveis: Um estudo empírico em instituições financeiras brasileiras.” Revista Portuguesa e Brasileira de Gestão 12 (2): 30-43.

Kang, K., J. Hahn, and P. De. 2017. "Learning effects of domain, technology, and customer knowledge in information systems development: An empirical study." Information Systems Research 28 (4): 797-811. https://doi.org/10.1287/isre.2017.0713

Kaplan, R. S. and D. P. Norton. 1992. "The balanced scorecard - measures that drive performance." Harvard Business Review 70 (1): 71-79.

Kayo, E. K., H. Kimura, D. M. L. Martin, and W. T. Nakamura. 2006. "Ativos intangíveis, ciclo de vida e criação de valor." Revista de Administração Contemporânea 10 (3): 73-90. https://doi.org/10.1590/S1415-65552006000300005

Keng, S., C. Lin, and P. F. Orazem. 2017. "Expanding College Access in Taiwan, 1978-2014: Effects on Graduate Quality and Income Inequality.” Journal of Human Capital 11 (1): 1-34. https://doi.org/10.1086/690235

Labidi, M. and J. F. Gajewski. 2019. "Does increased disclosure of intangible assets enhance liquidity around new equity offerings?" Research in International Business and Finance 48: 426-437.

https://doi.org/10.1016/j.ribaf.2019.01.009 
Luthy, D. H. 1998. “Intellectual capital and its measurement”. Paper presented at The Asian Pacific Interdisciplinary Research in Accounting Conference, Osaka, Japan, August, $4^{\text {th-6th. }}$

Magelssen, C. 2019. "Allocation of property rights and technological innovation within firms." Strategic Management Journal 41 (4): 1-30. https://doi.org/10.1002/smj.3103

Maqbool, R., Y. Sudong, N. Manzoor, and Y. Rashid. 2017. "The impact of emotional intelligence, project managers' competencies, and transformational leadership on project success: An empirical perspective." Project Management Journal 48 (3): $58-75$.

https://doi.org/10.1177/875697281704800304

Massingham, P. 2015. "Knowledge Accounts.” Long Range Planning 49 (3): 409-425. https://doi.org/10.1016/j.lrp.2015.02.003

Muller, R. and J. R. Turner. 2017. Project-oriented leadership. London: Routledge.

Nazir, M. S. and T. Afza. 2018. "Does managerial behavior of managing earnings mitigate the relationship between corporate governance and firm value? Evidence from an emerging market." Future Business Journal 4 (1): 139-156. https://doi.org/10.1016/j.fbj.2018.03.00

Ökten, N. Z., Elif Y. O., Ü. Arslan and M. O. Güngör. 2019. "The effect of brand value on economic growth: A multinational analysis.” European Research on Management and Business Economics 25: 1-7. https://doi.org/10.1016/j.iedeen.2018.11.002

Oliveira, A. O., H. L. S. Oliveira, C. F. S. Gomes, and P. C. C. Ribeiro. 2019. "Quantitative Analysis of RFID’ Publications from 2006 to 2016.” International Journal of Information Management 48: 185-192. https://doi.org/10.1016/j.ijinfomgt.2019.02.001

OECD (Organization for Economic Co-Operation and Development). 2008. Intellectual Assets and Value Creation. Synthesis Report. Accessed January 18, 2020. https://www.oecd.org/science/inno/40637101.pdf

Parr, R. L. and G. V. Smith. 1994. "Quantitative methods of valuing intellectual property." In The New Role of Intellectual Property in Commercial Transactions, edited by Melvin Simensky and Lanning G. Bryer, 39-68. New York: John Wiley.

Pastor, D., J. Glova, F. Liptak, and V. Kovac. 2017. "Intangibles and methods for their valuation in financial terms: Literature review." Intangible capital 13 (2): 387-410. https://doi.org/10.3926/ic.752

Reilly, R. F. and R. P. Schweihs. 1998. Valuing intangible assets. New York: McGraw-Hill.

Ribeiro, P. C. C., A. J. Scavarda, and M. O. Batalha. 2008. "The evaluation of information technology: a case study in Brazilian harvest facility." Journal of Operations and Supply Chain Management 1 (2): 65-76.

Roos, J. 1998. "Exploring the concept of intellectual capital (IC)." Long range planning 31 (1): 150-153.

Spender, J. C., P. Bednarz-Luczewska, A. Bordianu, and S. Rohaert. 2013. "Intangibles: Theory, Categories, and the Kozminski Matrix.” Knowledge Management Research \& Practice 11: 101-111. https://doi.org/10.1057/kmrp.2013.10 
Stewart, T. A. 1997. Intellectual Capital: The New Wealth of Organizations. New York: Doubleday/Currency.

Sullivan, P. H. 2000. Value driven intellectual capital: how to convert intangible corporate assets into market value. US: John Wiley \& Sons Inc.

Sveiby, K. E. 1997. "The intangible assets monitor." Journal of Human Resource Costing \& Accounting 2 (1): 73-97.

Sweeney, D. J., A. W. Thomas, and D. R. Anderson. 2015. Estatística aplicada à administração e economia. 3rd. ed. São Paulo: Cengage Learning.

Thum-Thysen, A., P. Voigt, C. Maier, B. Bilbao-Osorio, and D. Ognyanova. 2017. "Unlocking investment in intangible assets in Europe." Quarterly Report on the Euro Area (QREA) 16 (1): 23-35.

Tian, M., P. Deng, Y. Zhang, and M. P. Salmador. 2018. "How does culture influence innovation? A systematic literature review." Management Decision 56 (5): 1088-1107. https://doi.org/10.1108/MD-05-2017-0462

Van Marrewijk, A. 2007. "Managing project culture: the case of environ megaproject." International Journal of Project Management 25 (3): 290-299. https://doi.org/10.1016/j.ijproman.2006.11.004

Velibeyoğlu, K. and T. Yiğitcanlar. 2010. "An evaluation methodology for the tangible and intangible assets of city-regions: the 6K1C framework." International Journal Services Technology and Management 14 (4):343-359. https://doi.org/10.1504/IJSTM.2010.035783.

Viera, Á. F. G. 2017. “Técnicas de aprendizaje de máquina utilizadas para la minería de texto." Investigación bibliotecológica 31 (71): 103-126. https://doi.org/10.22201/iibi.0187358xp.2017.71.57812

Wang, M. 2013. "Value relevance on intellectual capital valuation methods: the role of corporate governance." Quality \& Quantity 47 (2): 1213-1223. https://doi.org/10.1007/s11135-012-9724-1

Para citar este texto:

Morais, Margareth Oliveira de, Carlos Francisco Simões Gomes e Priscilla Cristina Cabral Ribeiro. 2021. "Intangible assets in information technology projects: identification and evaluation". Investigación Bibliotecológica: archivonomía, bibliotecología e información 35 (86): 203-225. http://dx.doi.org/10.22201/iibi.24488321xe.2021.86.58311

\section{Appendix}

\section{Questionnaire and Answers}

1) What Region do you live?

Brazil - South Region - 23

Brazil -Southeast Region - 148

Brazil-Middle West Region - 14

Brazil - Northeast Region - 8

Brazil - North Region - 3

If you live abroad, please inform what country do you live: 1 (Dubai) 
2) Are you graduate in Management Information Systems (or similar) major? Yes - 146

No -50

3) Do you work in Information Technology (IT) department/sector/area?

Yes - 166

No - 30

4) Please, select all the alternatives that describe your experience in IT projects:

I have never worked in IT projects - 23

I work or I have already worked as technician/specialist/ consultant in IT projects - 147

I work or I have already worked as manager/leader of IT projects - 101

I work or I have already worked in IT projects as functional manager - 45

I work or I have already worked as program/portfolio manager in IT projects - 40

I work or I have already worked as sponsor in IT projects - 18

5) Please, inform your experience (time) in IT projects:

I do not have any experience in IT projects - 23

My experience in IT projects is less than 12 months - 17

My experience in IT projects is between 1 and 5 years - 43

My experience in IT projects is between 5 and 10 years - 41

My experience in IT projects is more than 10 years - 72

6) Please, select the alternative that features the project culture in the organization where you work currently:

There is not a project culture in the organization - 18

The project culture in the organization is embryonic - 29

There is a project culture, but there is not a project management's office - 49

There is a support/advisory project management's office (low control level) - 31

There is a project management control office (medium control level) - 29

There is a project management director office (high control level) - 17

7) Please, select the alternative that features better the size of organization where you work (does not matter your employment bond):

Micro enterprise - Trade and Service - until 09 employees - 25

Small enterprise - Trade and Service - between 10 and 49 employees - 20

Medium enterprise - Trade and Service - between 50 and 99 employees - 17

Large enterprise - Trade and Service - more than 100 employees - 39

Micro enterprise - Industry - until 19 employees - 1

Small enterprise - Industry - between 20 and 99 employees - 3

Medium enterprise - Industry - between 100 and 499 employees - 6

Large enterprise - Industry - more than 500 employees - 42

Others - 20 


\begin{tabular}{|c|c|c|c|c|c|c|c|c|c|c|}
\hline 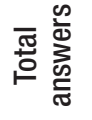 & $\stackrel{\Re}{\stackrel{\Re}{\sim}}$ & $\stackrel{\Re}{\stackrel{N}{\sim}}$ & $\stackrel{\Re}{\stackrel{N}{\sim}}$ & $\stackrel{\Re}{\stackrel{N}{N}}$ & $\stackrel{\mathfrak{N}}{\stackrel{2}{2}}$ & $\stackrel{\Re}{\stackrel{N}{ }}$ & $\stackrel{\Re}{\stackrel{N}{\sim}}$ & $\stackrel{\Re}{\stackrel{N}{\sim}}$ & 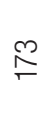 & $\stackrel{\mathscr{N}}{\stackrel{N}{\sim}}$ \\
\hline 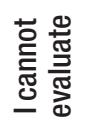 & $m$ & $\simeq$ & $\simeq$ & $\stackrel{m}{\longrightarrow}$ & $\mp$ & ஓి & $\approx$ & $\stackrel{\bullet}{\circ}$ & $\mp$ & ஓి \\
\hline
\end{tabular}

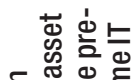

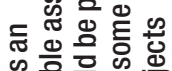

을음음 응 잉

들헝응

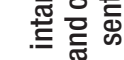

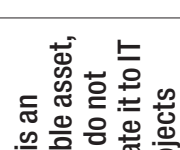

든 흗흥 응

플 으 क्

\begin{tabular}{|c|c|c|c|c|c|c|c|c|c|c|}
\hline 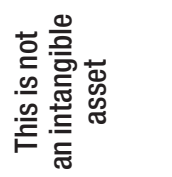 & $\Lambda$ & $\Lambda$ & $\Lambda$ & $\infty$ & 미 & $\stackrel{\sim}{d}$ & () & $\stackrel{\nabla}{\square}$ & $\mp$ & $\stackrel{\nabla}{\square}$ \\
\hline 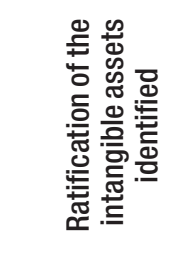 & 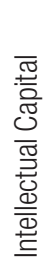 & 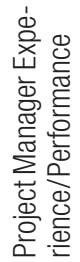 & 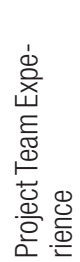 & 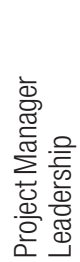 & 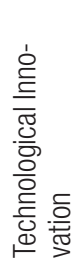 & $\begin{array}{l}\frac{D}{0} \\
\frac{\sqrt[N]{0}}{D}\end{array}$ & 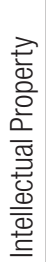 & 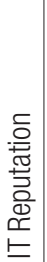 & 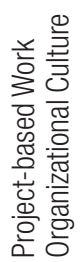 & 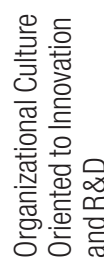 \\
\hline
\end{tabular}




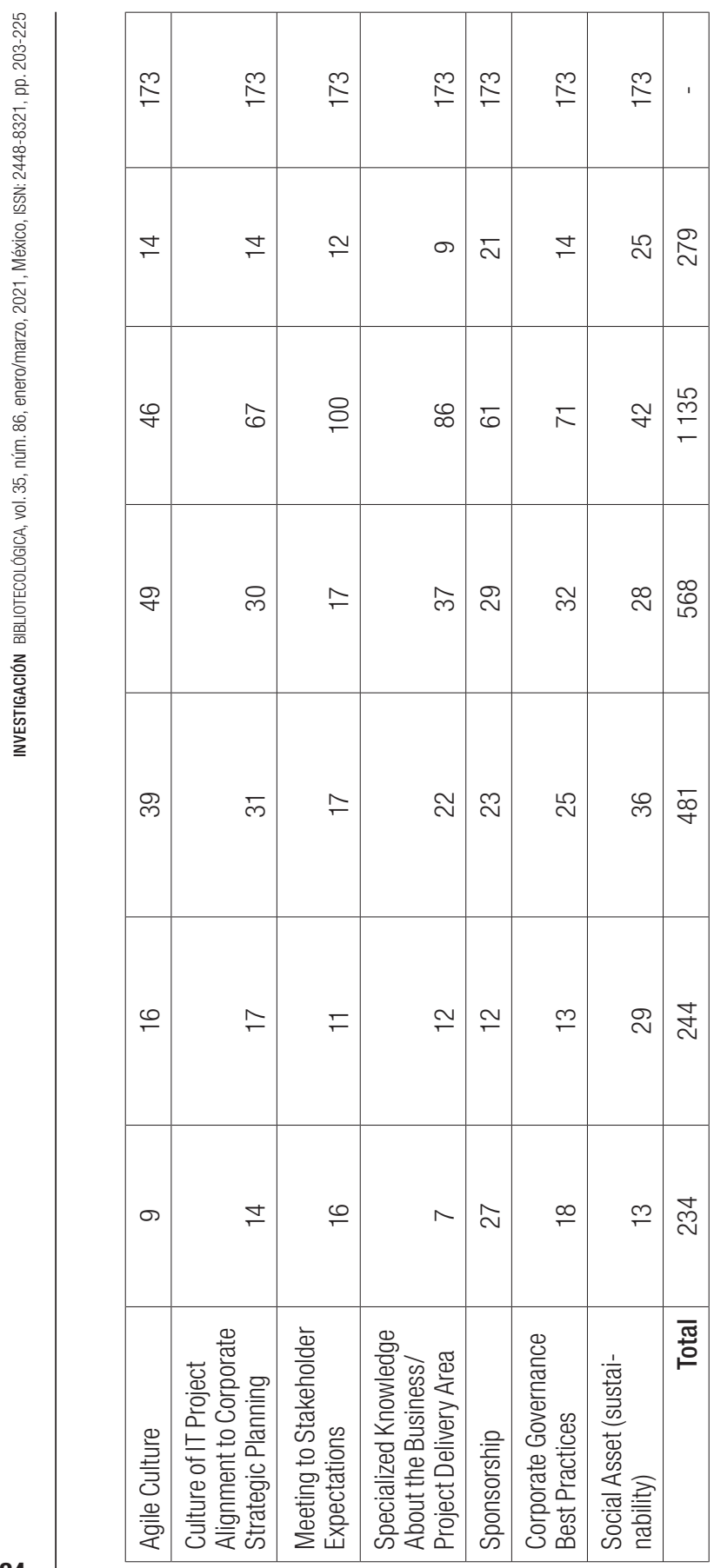


9) If you identify another intangible asset that could be present in IT projects and it was not mentioned in the question 8 , please, write below (optional answer):

R: There are seven intangible assets suggested:

- Organizational Process Assets;

- Negotiation skills;

- Culture for projects execution with multicultural teams;

- Culture for projects execution with teams geographically distributed;

- Project lessons learned;

- Creativity;

- Readiness and respect for projects deadlines and costs.

10) How do you consider the application of specific methods to assess the intangible assets, in the context of IT projects? Please, select all the alternatives that you consider appropriate:

( ) It can contribute to a better assessment of IT projects, in general - 118

( ) It can contribute to a better risk assessment of IT projects - 104

( ) It can contribute to a better assessment of the organization itself - 92

( ) I do not consider relevant the use of method to assess intangible assets in IT projects - 5

( ) I cannot assess, because I do not know methods for IT projects assessment 29

( ) I know methods for intangible assets assessment, but I do not know how to opine - 9 